Peer-Reviewed Article

ISSN: 2162-3104 Print/ ISSN: 2166-3750 Online

Volume 7, Issue 4 (2017), pp. 944-962

(C) Journal of International Students

http://jistudents.org/

doi: $10.5281 /$ zenodo. 1029675

\title{
Academic Advisors and Their Diverse Advisees: Towards More Ethical Global Universities
}

\author{
Yuko Ikegami Lee \\ University of British Columbia, Canada \\ Amy Scott Metcalfe \\ University of British Columbia, Canada
}

\begin{abstract}
In this comparative content analysis, job postings for academic advising personnel from U.S. and Canadian higher education institutions were examined to ascertain expectations for job candidates in terms of skills and duties, educational requirements, and compensation. Fifty-three job descriptions from 18 research-intensive, public universities were collected for this study. The findings show that institutions expect academic advisors to be multitalented and skilled professionals, but that calls for experience working with international students are limited, despite the rising importance of internationalization in higher education.
\end{abstract}

Keywords: academic advising, diverse students, international students

The number of international students arriving at U.S. and Canadian university campuses is steadily increasing (Canadian Bureau for International Education [CBIE], 2016; Institute of International Education [IIE], 2016; Kunin, 2012). In Canada, the number of international students at the university level reached 177,290 in 2015 . This number reflects a $92 \%$ increase in international students in Canada between $2008(184,170)$ and 2015 (353,570) for all levels of education (CBIE, 2016, p. 18). Similarly, the United States also saw a rise in its international students' enrollment on 
a larger scale. In the 2015/2016 academic year, a combined total number of the U.S. undergraduate and graduate international students reached 811,248 (IIE, 2016). This was an increase of $7.1 \%$ and $6 \%$ for undergraduate and graduate students respectively from the year before. While international student enrollments in both countries have increased, the current global political climate, marked by rising nationalism and xenophobia in countries such as the United States and the United Kingdom, Trump's 'America First' policy and Brexit to name a pair, may have an impact on international students' global mobility in the future. However, a fair number of colleges and universities are paying closer attention to factors that enhance international students' retention including strategically-distributed scholarship opportunities and financial incentives for international students (Bolsmann \& Miller, 2008). A key motivation for international students to seek university education abroad is to secure their favorable economic and social status at home and potentially in the host nation upon graduation (Mazzarol \& Soutar, 2002). During their university study, international students face many issues related to unmet expectations, racial stereotyping, and discrimination (Lee, 2010). These factors affect their academic performance and undermine their original objective of attending foreign universities. While many institutions offer academic advising to all students, academic advisors are ideally positioned to support international students' educational and broader future successes. However, the role of academic advisors is often not clearly defined or not proportionally and specifically assigned to the growing international student population. In this aspect, internationally well-versed academic advisors are needed to support the increasingly diversifying international student body of the Anglophone universities in the United States and Canada that strategically recruit international students.

The function of academic advisors can be different from one unit to the other, but they all work behind the scenes to support students' academic success. Thus, the role of academic advisors is often not fully understood by students, professors, and administrators, which hinders the effectiveness of this academic service role. Therefore, the aim of this study was to distinguish the roles, functions, and expectations of academic advisors who are non-faculty, professional staff members and examine how their role may serve as a holistic support for international students.

\section{BACKGROUND}


Higher education institutions and their service mechanisms have evolved over the last several centuries as enrollment has shifted from elite to mass and universal access (Trow, 1972, 2007). This growth has resulted in large classrooms and higher teacher-student ratios that make the traditional academic mentoring more difficult, even at private liberal arts colleges (Paris, 2013). Student composition has also changed drastically over the years (El-Khawas, 2003). As well, institutions have changed operationally. With the increase of a more academic capitalistic profession (Rhoades \& Slaughter, 1997; Slaughter \& Leslie, 1997), institutions have become used to hiring non-faculty professionals for cheaper alternatives to faculty labor as a cost saving measure. Therefore, many institutions are now systematically relying on a non-tenured workforce versus tenured professors to manage many aspects of institutional operations including educational services and student enrollment. Finally, Anglophone universities in the countries such as the United States, United Kingdom, Canada, and Australia have seen an influx of international students who seek 'English education' to improve their social mobility. The birth of the internet simply accelerated the monopoly of the English language in any global affairs including higher education.

\section{Definition of Academic Advising and Academic Advisors}

For this study, we define academic advisors as non-faculty staff members whose main responsibility is providing holistic academic-oriented support services to college and university students. Such services include academic advising, academic and career coaching, academic remedial support, academic performance evaluations, graduation checks, and any related matters that affect students' academic and emotional well-being. The initial form of the academic advising position emerged in the United States in response to a need to provide support for non-traditional and more diverse students in the 1960s. Ever since, academic advising has focused on providing holistic student support to all students including remedial support for the marginalized and minority students on campus (King, 1993). One result of widening access to higher education has been that there are more students coming to universities with inadequate academic preparation or financial challenges that severely undermine their chances of academic success. While remedial academic support for at-risk students is certainly the major focus for academic advisors, it should be noted that an unforeseen 
crisis or emergency situation can occur to anyone, even otherwise academically strong students.

Academic advisors are mandated to support students during their studies, but this role can take various forms (Drake, 2011, 2013; Nuss, 2003). In this evolving field, the professional development literature outlines three types of academic advising methods that are commonly practiced (Donaldson, McKinney, Lee, \& Pino, 2016). In prescriptive advising, academic advisors guide students similar to the ways that a doctor prescribes treatment for their patients. In developmental advising, academic advisors follow the cues that are given by students, encouraging students to remain in the driver seat in their own education. Thirdly, intrusive advising takes more proactive approaches to add a systematic approach in the advisor-advisee relationship such as regularly monitoring students' progress and providing proactive coaching. It is important to note that each technique is not exclusive to one another and can be applied simultaneously or consecutively with students. The Global Community for Academic Advising (NACADA) and its regional groups offer training for academic advisors. Advanced degrees in academic advising are also available. Resources such as Academic Advising: A Comprehensive Handbook (Gordon, Habley, \& Grites, 2011) support the profession as well.

At a minimum, academic advisors must possess accurate knowledge of the degree requirements and opportunities in order to advise students, but it is also as important for them to possess a high degree of soft skills (Crosbie, 2005) in order to engage advisees. Academic advisors also need to be resourceful and acutely aware of alternative options for students who may be required to interrupt or terminate their studies and move on. Accumulation of professional skills, disciplinary knowledge, and international experiences help academic advisors to holistically support international students in time of a crisis. It is also helpful if they possess a high level of resiliency and emotional intelligence (EI). Caruso and Wolf (2001)'s theory of EI in the workplace informs us that a manager's own emotional state can affect others in the workplace. If so, when advisees seek advising, academic advisors' EI should matter as academic advising occurs in a setting that is similar to a workplace. Additionally, Marks and Wade (2015) argued that "faculty and staff who know and give emphasis to their students' strength can create positive expectations" and suggested the importance of "acknowledging his [sic] difficulties" (p. 12) while tapping into advisees' previous success as an example of how academic advisors can develop a more engaging relationship with advisees. 


\section{Academic Advisors as Catalysts}

Academic advisors are dynamic participants (Dalton, 2003) of a campus community and are central to institutional strategies, especially internationalization. In this notion, academic advisors act as catalysts on campus. Therefore, they function best when the role receives "buy-in" from the students, professors, and administrators of the unit where academic advisors are assigned. Supporting international students typically requires a high degree of on-the-ground coordination because of the added complexity of this particular student group, whose domestic supports (e.g., family members and larger community) are not nearby or immediately available. To support the academic aspirations of students, one must be knowledgeable of different academic options such as the logistics of course registration and appropriate course load within the academic policies and regulations that they observe. Furthermore, experienced academic advisors also look for any tangible and intangible evidence during advising interactions that could help in coming up with appropriate solutions, with the academic and greater well-being of the students in mind. When it comes to academic advising, a blanket approach usually leaves the most vulnerable feeling unsupported or unfairly treated. International students from non-English speaking countries often require extra attention by the institution and its personnel due to their cultural, social, and emotional differences (Lee \& Rice, 2007). As well, the consequences for academic failure are higher for international students, as their academic standing can affect their legal status in the host country. In addition, some international students are sponsored by organizations such as governments and corporations, which sometimes restricts their course selections, meaning that registering for a wrong course could affect their funding eligibility. All these added precautions must be understood by receiving institutions, and especially their academic advisors, in order to support such students. As such, academic advisors need to be trained and supported to address the additional obstacles their international students face when compared with their domestic student peers.

Furthermore, many scholars argued that international students need additional support to overcome potential disadvantages in academic, social, and emotional fronts when pursuing higher education in foreign countries (Fox, 1994; Lee, 2010). In turn, those universities will benefit from having them join the campus community for more ethical reasons than just for the premium tuition fees. The evidence that connects academic advising and student loyalty was also discovered by Vianden and Barlow (2015) through 
their multi-institutional study. Understanding the position that academic advisors are locating directly in-between institutions and international students, academic advisors can be supported to be effective catalysts towards a more ethical and humanistic higher education environment.

\section{RESEARCH METHOD}

We compared U.S. and Canadian job announcements in an effort to understand how these two receiving countries of international students view academic advisors who are hired to provide academic services to all students, including international students. The U.S. institutions in the sample were the top 10 of the U.S.-based public institutions listed in the 2015 Academic Ranking of World Universities (ARWU). As for the Canadian case, we included the 13 Anglophone institutions in the "U15," which are understood to be the leading research universities in the country (Appendices A and B). Many of these institutions possess a significant number of international students in their undergraduate student body. Among those institutions chosen, there is a significant difference in the percentage of international student enrollment on campus between $8 \%$ and $29 \%$ (see appendices). The Canadian universities tend to be higher in international student percentage (averaged at 18\%) compared to the American counterparts (averaged at 13\%).

Applicable job postings were collected from the human resources (HR) websites of each institution during the month of September in 2016. In the initial data collection phase, the search terms of advisor, academic advising, student affairs, and international were used. Fifty-nine job postings, including 40 from the U.S. institutions and 19 from the Canadian institutions, were collected from the institutional websites. Where possible, further exploration of the HR sites was carried out in order to determine the starting salaries of the postings. This additional review was necessary because some job postings did not list the exact dollar figures but instead mentioned the pay scale or pay grade.

During the primary screening phase, we looked for two key terms in the position announcements: advisor and academic advising. Although eligible job postings were collected at all of the $10 \mathrm{US}$ institutions, only the eight U15 institutions had eligible job postings after the screening. Finally, a total of 53 job descriptions, 37 from the 10 U.S. institutions and 16 from the eight Canadian institutions, were advanced for analysis in this study. 
Upon initial observation of the 53 job postings, we found that a typical job description included several key categories such as the general information about the institution, unit/departmental overview, benefits and salary compensation, job duties, skills and competencies, and disclaimers. For the purpose of this study, we decided to divide these categories into two sections: the human resource basic questions (Section 1) and the specific jobs and the skills required (Section 2). Section 1 criteria were further placed into six sub-categories such as the level of education required, organizational scope, type(s) of advisees, starting salaries, and professional development. Although Section 2 were divided into two categories only, the job duties and the skills and competencies, Section 2 produced the majority of data points for this study with up to 60 categorical variables. These variables were purposefully sorted into clusters of similar items based on the nature of the variables, and they were eventually reduced to the 26 job duties and the 36 skills and competencies clusters. With the two sections, over 7,500 data points were collected to produce the findings of this study.

\section{FINDINGS}

\section{Starting Salaries and Required Education Level}

In this study, the compensation rate (starting salary) was collected from the job announcements. Canadian salaries were converted to U.S. dollars (USD) for the purpose of comparison. In those cases, where salaries were listed at hourly or weekly rates, we adjusted the figures to an annual salary. The majority of the job postings indicated starting salaries between $\$ 30,000$ USD and $\$ 50,000$ USD. According to the data published by the Chronicle of Higher Education (2016), the average salary of the Librarians/Ed. Services (Carnegie classification, high research institutions) category between 2012 and 2016 was $\$ 50,231$ USD. To provide a further reference point for this figure, the average salary in 2015 in the United States was $\$ 41,714$ ( $\$ 802$ weekly) USD and $\$ 34,657$ ( $\$ 667$ weekly) USD in Canada. It is also important to note that salaries and wages of the same occupation can vary depending on the geographic location in both and between the two countries. This is largely due to the cost of living of the particular location, but that is not all. In this study, as some institutions are in urban areas and others are not, the face value of annual income does not necessarily tell us the actual value of the income in relation to the purchasing power. For example, the University of British Columbia campus in Vancouver, BC, Canada, is affected by the skyrocketing housing price of 
the city, making housing affordability one of the most important factors for recruitment and retention of faculty and staff members. In the higher education setting, other factors such as perceived organizational support (POS) can also attribute to its staff members' commitment for their institutions and could influence their motivation or organizational loyalty (Fuller, Hester, Barnett, \& Relyea, 2006).

Each of the job descriptions in our sample mentioned educational qualifications, mostly at the Bachelor's or Master's degree levels. The minimum education requirement roughly corresponded to the salary range, with the higher earning positions requiring Master's degrees in specific fields (Table 1). There is a stronger preference for the "specific" and advanced degrees such as higher education and counseling psychology among the U.S. institutions. This perhaps reflects a more established professional environment for academic advising in the United States than in Canada.

Table 1: Minimum education requirement and starting salaries $(\mathrm{N}=36)$

\begin{tabular}{|c|c|c|c|c|c|}
\hline \multirow{2}{*}{$\begin{array}{l}\text { Starting salary } \\
\text { (\$US) }\end{array}$} & \multicolumn{2}{|c|}{ Master's degree } & \multicolumn{2}{|c|}{$\begin{array}{c}\text { Undergraduate } \\
\text { degree }\end{array}$} & \multirow{2}{*}{$\begin{array}{c}\text { Associate } \\
\text { degree/ } \\
\text { HS } \\
\text { diploma }\end{array}$} \\
\hline & Specific & General & Specific & General & \\
\hline Below 30,000 & 0 & 0 & 1 & 1 & 0 \\
\hline $30,001-40,000$ & 1 & 0 & 6 & 11 & 1 \\
\hline $40,001-50,000$ & 1 & 0 & 9 & 3 & 1 \\
\hline $50,001-60,000$ & 0 & 0 & 0 & 0 & 0 \\
\hline $60,001-70,000$ & 1 & 0 & 0 & 0 & 0 \\
\hline
\end{tabular}

While higher education attainment is preferred, the lowest education requirement was also found among the U.S. institutions. A completion of a high school diploma or an associate degree was mentioned in two U.S. postings. On the other hand, the minimum educational attainment required by the Canadian institutions was a bachelor's degree. Eleven (11) out of 15 Canadian job postings listed their starting salaries between $\$ 30,001$ and $\$ 40,000$ USD. In contrast, twenty (20) out of 21 jobs in the United States listed the salaries between $\$ 40,001$ and $\$ 60,000$ USD. This wage gap between the two countries might be partially explained by the favorable U.S. currency exchange rate against Canadian dollars in recent years. In fact, since the last time those currencies were at par in 2010, Canadian dollars 
have been dropping and maintained its value roughly about $30 \%$ less to their U.S. counterpart. As a snapshot, the published currency exchange rate was 1 USD to 1.33382 CAD as of June 2017. On the other hand, some Canadian institutions may offer other forms of occupational compensation, including pensions and health insurance that do not show as salary per se.

\section{Job Duties}

Although our central criteria for inclusion in the study were that the job descriptions contain terms related to academic advising in their position titles and job summaries, surprisingly a few of the job announcements did not mention the term "academic advising" as an explicit job duty at all. There were some job descriptions that did not entirely match the job titles. Although $87.9 \%$ of the sample job announcements listed academic advising as a distinct job duty (Table 2), a few job descriptions were more focused on other duties, such as immigration counseling or student well-being. Our sample also included job announcements with job titles such as graduate student affairs officer (U.S.), enrollment information advisor (Canada), and international student advisor (Canada). We see these varieties of job titles as an indication that institutions are making an effort to accommodate different needs of their students. Although the explicit job title "international student advisor" was noted, it was a rarity in the sample.

Since international students require legal status to study in a foreign country, having the proper support to ensure their status is essential. However, it is unreasonable to expect that academic advisors serve as immigration counselors. For instance, in Canada, the position of international student advisor is largely treated as a synonym for regulated Canadian immigration consultants (RCIC) or regulated international student immigration advisors (RISIA), who are certified experts in immigration consultation in Canada. This "bundling" of skills is becoming more common and creating some confusion in terms of what international students need and who will respond to those needs, but it is important to distinguish academic advisors and immigration specialists who have different mandates. With that foundation, it is most effective for academic advisors and immigration specialists to work collaboratively. 
Table 2: Top 10 job duties

\begin{tabular}{lccc} 
Duties required & $\begin{array}{c}\text { Combined } \\
\text { average }\end{array}$ & U.S. & Canada \\
\hline Academic advising & 87.9 & 94.6 & 81.3 \\
Programming and delivery & 87.4 & 81.1 & 93.8 \\
Collaborate and refer & 65.9 & 56.8 & 75 \\
Recruitment and outreach & 57 & 70.3 & 43.8 \\
Research, data assessment, report & 43.5 & 43.2 & 43.8 \\
Career advising & 42.1 & 40.5 & 43.8 \\
Financial aid and awards & 40.8 & 37.8 & 43.8 \\
Website and social media & 39.9 & 29.7 & 50 \\
Admissions & 39.4 & 35.1 & 43.8 \\
Business development & 35 & 32.4 & 37.5 \\
\hline (\% of that group) & & &
\end{tabular}

Table 3: Top 10 job skills

\begin{tabular}{lccc}
\hline Skills required & $\begin{array}{c}\text { Combined } \\
\text { average }\end{array}$ & U.S. & Canada \\
\hline $\begin{array}{l}\text { Communication skills } \\
\text { Knowledge in policies } \\
\text { (academic-related policies and }\end{array}$ & 97.3 & 95 & 100 \\
procedures) & 77.1 & 73 & 81.3 \\
IT proficiency & 69.9 & 64.9 & 75 \\
Decision making skills & 67.2 & 59.5 & 75 \\
Time management and & 59.5 & 37.8 & 81.3 \\
prioritizing & & & \\
Ability to work with diverse & 58.8 & 67.6 & 50 \\
populations & 55.7 & 67.6 & 43.8 \\
Advising skills & 48.4 & 40.5 & 56.3 \\
Service oriented & 47.9 & 27 & 68.8 \\
Diplomacy, tact, and discretion & 44.8 & 45.9 & 43.8 \\
Multitasking & & & \\
\hline (\% of that group) & & & \\
\hline
\end{tabular}

\section{Skills and Competencies}

A list of categorical variables concerning skills and competencies were produced, with communication skills being the most sought after competencies for both countries (Table 3). Since we found over 60 categorical variables in this area, it was necessary to cluster them according 
to their similarities. For example, "communication" was bundled with written, verbal, public speaking and presentation skills. Similarly, we combined "sound judgment" and "decision making skills." While an understanding of the academic discipline that academic advisors serve is necessary, as this result shows, having superior communication skills appears to supersede the technical disciplinary knowledge, from the employer's perspective. Perhaps this is to be expected, as the content experts are the faculty members who teach the courses, but we note that academic advisors are intended to interact with students in relation to class assignments and overall comprehension of course material.

The job skills and competencies that were asked of the incumbents were comprehensive. While some highly subjective attributes were required in some of the postings such as a sense of humor or an advocacy for social justice, others required very specific and technical skills that may not directly associate with academic advising such as proficiency in Adobe Creative Suite and Adobe InDesign. Overall observations of the skills and competencies requested confirmed that academic advisors are required to be multitalented or require skills that are not clearly defined. Interestingly, of the skills that we think would be most useful to support international students, the ability to work with diverse populations was not mentioned as frequently in the job descriptions as more "nuts and bolts" understandings of academic policy or proficiency with information technology. This possibly can be explained by the invisible nature of the educational and student services offered on campus by professional staff like academic advisors. There may be some regional or national differences in these expectations, as the "soft skills" of diplomacy, tact, and discretion were infrequently noted in the U.S. sample (27\%), but more frequently listed on the Canadian job descriptions $(68.8 \%)$.

A small number of the job descriptions examined in this study show evidence of an interest in the job candidates' soft skills and teaching capabilities, as seen in the following examples:

- "Training of faculty advisors to ensure student progress through course sequences by avoiding conflicts, promoting consistency, and ensuring compliance with campus-wide policies." - Student Academic Advisor, biological sciences program, U.S. institution

- "This position advises and orients visiting course instructors regarding course-related academic policies and departmental practices, grading processes, accommodation policies." - Student Advisor, undergrad business program, U.S. institution 
- "Experience teaching and/or conducting workshops for college students." - Academic Counselor, engineering program, U.S. institution.

\section{Deliberate Hiring Efforts?}

We also looked for the specific term "international student" in the job announcements (Table 4). Although the number of announcements that included "international student" was higher among Canadian institutions, we found this was due to the country's unique legal restrictions on who is legally allowed to provide students with advice regarding their study visas and descriptions of this certification in the job announcements. In Canada, consultations that provide immigration advising, including study permit matters, must be the members of the Immigration Consultations of Canada Regulatory Council (ICCRC). ICCRC is a federally organized professional association for the Regulated Canadian Immigration Consultants (RCICs) and the Regulated International Student Immigration Advisors (RISIAs). While they are important professional service providers to university students, their field is already specialized enough and their mandates are within the boundary of the professional association that they are different from what academic advisors are expected to do. It is needless to mention that all specialized advisors at higher education institutions work collaboratively already, but it may be hard to differentiate those roles by others on campus since they both work with international students in separate, but also distinguished ways.

Table 4: The use of the term "international student"

\begin{tabular}{lccc}
\hline & $\begin{array}{c}\text { Combined average } \\
\text { (negative result only) }\end{array}$ & YES & NO \\
\hline U.S. institutions & 72 & 24 & 76 \\
Canadian institutions & & 37.5 & 62.5 \\
\hline (\% of that group) & &
\end{tabular}

\section{DISCUSSION}

As we conducted the content analysis of academic advisors' job descriptions, a few key factors emerged that deserve further discussion in order to bring more attention to the ways in which academic advisors can function more effectively in supporting international students. If institutions 
are successful in supporting academic advisors to do their job more effectively, satisfaction and outcome of international students' academic endeavors in their host institutions can be improved. As we discussed before, supporting international students once they arrive on campus requires a multi-layered support by many student services units and personnel. Academic advisors could contribute at the foundation level of a more ethical internationalization strategy. Academic advising requires longterm interactions with international students compared to the one-time recruitment phase upon which institutions often focus.

\section{Soft Skills}

First, throughout our review of the job descriptions, it became apparent that soft skills are required to succeed in this role. Soft skills are defined as "personality traits, goals, motivations, and preferences that are valued in the labor market, in school, and in many other domains" by Heckman and Kautz (2012). This definition is applicable to many of academic advisors' job duties that require their discretion, tact, and diplomacy. The problem is that soft skills are difficult to measure. Relationship building also requires intangible skills and genuine goodwill by service professionals. Respecting the academic policies and regulations is important in academic advising, but academic advisors must practice their decision-making power with a thorough and deep understanding in culture, history, and the current sociopolitical situation of the advisees in mind and treat each case individually. Soft skills are important to elicit advisees' responses to better understand the individual situation of each advisee. Otherwise, due to an insufficient awareness of the certain cultural and power dynamics, academic advising may cause harm and reproduce inequity despite the academic advisor's intention (Stewart, 2012).

\section{Intentional Hiring and Continued Training}

While academic advisors should consider themselves professional educational service providers, their skills and expertise also need to be updated, as with any respected profession. For example, professional organizations encourage academic advisors to familiarize themselves with relevant educational theories in the fields such as youth and young-adult cognitive development or university teaching and learning. Ryan (1992) and other scholars (Drake, 2013; Miller \& Alberts, 1994) argue that there are similarities between academic advising and university teaching. From this perspective, investment in academic advisors' professional development 
should be considered necessary for higher education institutions and the environment and to do so should be built into university operations (e.g., academic study leaves or workshop attendance).

\section{CONCLUSION}

By raising awareness of the role of academic advisors, we hope to bring a focus to an authentic support culture for the growing body of international students and similarly increasing "domestic" students with diverse backgrounds. Understanding the role of academic advisors and providing effective support and professional development opportunities would cultivate this culture.

Based on our findings, academic advisors are not only expected to be highly trained, but also to be active agents in the higher education context. We cannot overstate the importance of developing a trusting relationship among every student services unit on campus as well as between professors and administrators in order to support students holistically (Schuh, Jones, Harper \& Associates, 2010). In our view, academic advisors are not only uniquely positioned to enhance this notion, but also are vital to the success of institutional internationalization objectives.

Many of the job descriptions we examined had entrusted academic advisors with initiatives in several key student services areas such as recruitment, admissions, degree audit, graduation, and career development of their advisees. However, a few of the job descriptions fell far short of a comprehensive understanding of the potential of this role. As well, we found that explicit support for international students or an increasingly global student population was rarely acknowledged.

From this analysis, we have some recommendations for ways that universities can recognize academic advisors' skills and for furthering their professional development. For example, the academic advisor's role could become more professionalized along the lines of university librarians, who often hold faculty status. Considering their tight work cycle and some emotionally demanding matters of advisees that they encounter, academic advisors would benefit from more systematic off-duty opportunities such as a paid study leave or a mental health break that are built into their work schedule. Opportunities to pursue further education are motivational and could avoid burnout. Depending on the student populations they serve, it could be useful for academic advisors to have professional development 
opportunities abroad. We often emphasize the importance of study abroad for students, and the same principles hold true for university employees. This could be achieved in the form of participation in international staff exchange and international student recruitment trips in foreign countries.

\section{REFERENCES}

Bolsmann, C., \& Miller, H. (2008). International student recruitment to universities in England: Discourse, rationales and globalisation. Globalisation, Societies and Education, 6(1), 75-88.

Canadian Bureau for International Education (CBIE). (2016). A world of learning, 2016. Retrieved from http://net.cbie.ca/download/World-of-Learning2016-EN.pdf

Chronicle of Higher Education. (2016). Chronicle Data. Retrieved from https://data.chronicle.com/

Crosbie, R. (2005). Learning the soft skills of leadership. Industrial and Commercial Training, 37(1), 45-51.

Dalton, J. C. (2003). Managing human resources. In S.R. Komives \& D.B. Woodard, Jr. (Eds.) Student services: A handbook for the profession, (4th ed., pp. 397-419). San Francisco, CA: Jossey-Bass.

Donaldson, P., McKinney, L., Lee, M., \& Pino, D. (2016). First-year community college students' perceptions of and attitudes toward intrusive academic advising. NACADA Journal, 36(1), 30-42.

Drake, J. K. (2011). The role of academic advising in student retention and persistence. About Campus, 16(3), 8-12.

Drake, J. K. (2013). Advising as teaching and the advisor as teacher in theory and in practice. In J. K. Drake, P. Jordan, M. A. \& Miller, (Eds.), Academic advising approaches: Strategies that teach students to make the most of college, (pp.17-32). San Francisco, CA: John Wiley \& Sons.

El-Khawas, E. (2003). The many dimensions of student diversity. In S. R. Komives \& D. B. Woodard, Jr. \& Associates (Eds.). Student services: A handbook for the profession (pp.45-52). San Francisco, CA: Jossey-Bass.

Fox, H. (1994). Listening to the world: Cultural issues in academic writing. Urbana, IL: National Council of Teachers of English.

Fuller, J. B., Hester, K., Barnett, T., \& Relyea, L. F. C. (2006). Perceived organizational support and perceived external prestige: Predicting organizational attachment for university faculty, staff, and administrators. The Journal of Social Psychology, 146(3), 327-347.

Gordon, V. N., Habley, W. R., \& Grites, T. J. (Eds.). (2011). Academic advising: A comprehensive handbook. ( ${ }^{\text {nd }}$ ed.). San Francisco, CA: Jossey-Bass.

Heckman, J. J., \& Kautz, T. (2012). Hard evidence on soft skills. Labour economics, 19(4), 451-464. 
Institute of International Education. (2016). International students by academic level, 2014/15 - 2015/16. Open Doors report on international educational exchange. Retrieved from http://www.iie.org/opendoors

King, M. C. (1993). Academic advising, retention, and transfer. In M.C. King (Ed.). Academic advising: Organizing and delivering services for student success. (New Directions for Community Colleges, No. 82, 21-31). San Francisco, CA: Jossey-Bass.

Kunin, R. (2012). Economic impact of international education in Canada - an update, final report. (pp. ii-53). Vancouver, British Columbia: Rosalyn

Kunin \& Associates. Retrieved from http://www.international.gc.ca/education/assets/pdfs/economic_impact_en. pdf

Lee, J. J. (2010). International students' experiences and attitudes at a U.S. host institution: Self-reports and future recommendations. Journal of Research in International Education, 9(1), 66-84.

Lee, J. J., \& Rice, C. (2007). Welcome to America? International student perceptions of discrimination. Higher Education, 53(3), 381-409.

Mazzarol, T., \& Soutar, G. N. (2002). "Push-pull” factors influencing international student destination choice. International Journal of Educational Management, 16(2), 82-90.

Miller, M. A., \& Alberts, B. (1994). Developmental advising: Where teaching and learning intersect. NACADA Journal, 14(2), 43-45.

Nuss, E. M. (2003). The development of student affairs. In S.R. Komives \& D.B. Woodard, Jr. (Eds.), Student services: A handbook for the profession, 4th ed., (pp. 65-88). San Francisco, CA: Jossey-Bass.

Paris, D. (2013). The last artisans? Traditional and future faculty roles. Peer Review, 15(3), 17-20.

Rhoades, G. \& Slaughter, S. (1997). Academic capitalism, managed professionals, and supply-side higher education. Social Text, (51), 9-38.

Ryan, C. C. (1992). Advising as teaching. NACADA Journal, 12(1), 4-8.

Marks, L. I., \& Wade, J. C. (2015). Positive psychology on campus: Creating the conditions for well-being and success. About Campus, 19(6), 9-15.

Schuh, J. H., Jones, S. R., \& Harper, S. R. and Associates (Eds.). (2010). Student services: A handbook for the profession. ( $5^{\text {th }}$ ed.). San Francisco, CA: Jossey-Bass.

Slaughter, S., \& Leslie, L. L. (1997). Academic capitalism: Politics, policies, and the entrepreneurial university. Baltimore, MD: The Johns Hopkins University Press.

Stewart, D. L. (Ed.). (2012). Multicultural student services on campus: Building bridges,re-visioning community. Sterling, VA: Stylus Publishing, LLC.

Trow, M. (1972). The expansion and transformation of higher education. International Review of Education, 18(1), 61-84. 
Trow, M. (2007). Reflections on the transition from elite to mass to universal access: Forms and phases of higher education in modern societies since WWII. In J.J.F. Forest \& P.G. Altbach (Eds.). International handbook of higher education (pp. 243-280). Dordrecht, Netherlands: Springer.

Vianden, J., \& Barlow, P. J. (2015). Strengthen the bond: Relationships between academic advising quality and undergraduate student loyalty. The Journal of the National Academic Advising Association, 35(2), 15-27.

\section{APPENDIX A}

Sample of the U.S. institutions

The top ten public institutions were selected from the Academic Ranking World Universities 2016. Total enrollment and international student percentage data was taken from the Times Higher Education World University Ranking website.

\begin{tabular}{|l|c|c|}
\hline Name of institution & Total enrollment & $\begin{array}{c}\text { International student } \\
\text { percentage }\end{array}$ \\
\hline University of California, Berkeley & 34834 & $16 \%$ \\
\hline University of California, Los & 38392 & $16 \%$ \\
\hline University of California, San Diego & 28416 & $14 \%$ \\
\hline University of California, San & 3141 & N/A \\
\hline University of Colorado, Boulder & 29741 & $9 \%$ \\
\hline University of Michigan - Ann Arbor & 41912 & $16 \%$ \\
\hline University of Minnesota, Twin Cities & 46625 & $8 \%$ \\
\hline University of North California at & 26412 & $15 \%$ \\
\hline University of Washington & 45162 & $12 \%$ \\
\hline University of Wisconsin - Madison & 40048 & $8 \%$ \\
\hline
\end{tabular}

*Data was retrieved from the website on June 14, 2017 (https://oir.ucsf.edu/studentenrollment-headcount). 


\section{APPENDIX B}

Sample of Canadian institutions

These institutions were selected from a group of research universities in Canada also known as the U15 consortium. Two Francophone universities were excluded from this study due to the language limitation. Total enrollment and international student percentage data was taken from the Times Higher Education World University Ranking website.

\begin{tabular}{|l|c|c|}
\hline Name of institution & Total enrolment & International student \% \\
\hline University of Alberta & 33159 & $24 \%$ \\
\hline University of British Columbia & 51889 & $29 \%$ \\
\hline University of Calgary & 28047 & $18 \%$ \\
\hline University of Dalhousie* & 15293 & $19 \%$ \\
\hline University of Manitoba & 29111 & $13 \%$ \\
\hline McGill University & 30911 & $24 \%$ \\
\hline McMaster University*** & 27987 & $15 \%$ \\
\hline University of Ottawa & 34946 & $11 \%$ \\
\hline Queen's University & 21015 & $16 \%$ \\
\hline University of Saskatchewan* & 19154 & $15 \%$ \\
\hline University of Waterloo & 31776 & \\
\hline Western University & 28060 & \\
\hline University of Toronto* & 68093 & \\
\hline University HR sites wer & & \\
\hline
\end{tabular}

*University HR sites were monitored, but no applicable postings were found during the data collection period (September 2016).

**Retrieved from the website on June 14, 2017

(http://www.mcmaster.ca/opr/html/opr/fast_facts/main/about.html) 
YUKO IKEGAMI LEE, M.Ed., is a practitioner-scholar at the University of British Columbia. In her role as an International Student Advisor-Recruiter, she has a keen interest in developmental academic advising and also promoting diversity and inclusion on campus. Email: ikegamiyuko@gmail.com

AMY SCOTT METCALFE, Ph.D., is an Associate Professor in the Department of Educational Studies at the University of British Columbia. Her research interests focus on higher education policy, internationalization, and faculty labor and identity. Email: amy.metcalfe@ubc.ca 